\title{
ANALISIS KINERJA KEUANGAN BERDASARKAN RASIO SOLVABILITAS PADA PT. BPD SUMATERA BARAT
}

\author{
Ivani Amelia, Afriyeni \\ Akademi Keuangan dan Perbankan Padang \\ Afriyeni.yen@gmail.com
}

\begin{abstract}
The purpose of this study was conducted to determine the level of solvency PT. BPD of West Sumatra in 2013 - 2015. The method used is the method of Qualitative and Quantitative. Data collection was done by secondary data such as financial statements. BPD of West Sumatra. The results could be seen in 2013 to 2015 with the average - average Debt to Total Assets Ratio is obtained by 89.86\%, while the ratio of Debt to Equity Ratio in 2013 to 2015 obtained by the average - average ratio of 923.08\%, Ratio Long term Debt to Equity ratio in 2013 to 2015 obtained by 55.27\%, and the ratio time Interest earned in 2013 to 2015 obtained by the average - average of 0.42 times. Thus we can conclude that the solvency ratio of PT. BPD good because PT. BPD of West Sumatra able to pay off the entire debt both from the company and from the company's capital assets owned.
\end{abstract}

\section{LATAR BELAKANG}

Saat ini peranan dan fungsi bank sangat dirasakan oleh masyarakat, mulai dari kalangan menengah ke atas maupun kalangan menengah ke bawah. Hal ini terjadi karena kebutuhan masyarakat belum sepenuhnya terpenuhi dari penghasilan yang mereka peroleh. Oleh sebab itu jasa yang ditawarkan oleh bank menjadi sasaran masyarakat untuk menunjang perekonomian. Berkembangnya dunia perbankan saat ini diharapkan mampu mempertahankan likuiditas dan solvabilitas perusahaannya karena jika bank tidak mampu bersaing dan memenuhi permintaan masyarakat maka bank tersebut akan pailit.

Menurut Undang - undang RI Nomor 10 tahun 1998 tentang perbankan, pengertian bank adalah badan usaha yang menghimpun dana dari masyarakat dalam bentuk simpanan dan menyalurkannya kepada masyarakat dalam bentuk kredit atau bentuk lainnya dalam rangka meningkatkan taraf hidup rakyat. Dalam operasionalnya bank menghimpun dana dalam bentuk sertifikat deposito dan produk lainnya dengan tujuan investasi bagi masyarakat. Selanjutnya bank menyimpan dana masyarakat dalam bentuk tabungan dan giro dan menyalurkan 
dana dalam bentuk kredit. Hal ini berkaitan dengan tujuan bank untuk mensejahterakan kehidupan masyarakat.

Bank dibagi menjadi dua bagian yaitu bank umum dan bank perkreditan rakyat. Bank umum merupakan bank yang melaksanakan kegiatan usaha secara konvensional maupun syariah yang dalam kegiatannya memberikan jasa untuk lalu lintas pembayaran. Sedangkan bank perkreditan rakyat yaitu bank yang melaksanakan kegiatan usaha secara konvensional ataupun syariah yang dalam kegiatannya tidak menyediakan jasa lalu lintas pembayaran.

Untuk melihat kinerja suatu bank dapat dilihat dari laporan keuangan yang telah dipublikasi. Laporan keuangan yang diterbitkan oleh bank yang memberikan informasi posisi dan kondisi keuangan, akan tetapi laporan keuangan tersebut perlu di analisis lebih lanjut dengan menggunakan alat analisis keuangan untuk memperoleh informasi yang spesifik tentang kondisi dan kemampuan bank tersebut. Salah satu rasio keuangan yang digunakan untuk menilai kondisi keuangan dan kemampuan bank adalah rasio solvabilitas.

Dengan menggunakan alat analisis rasio solvabilitas dapat diketahui beberapa hal yang berkaitan dengan penggunaan modal sendiri dan modal pinjaman serta mengetahui kemampuan bank dalam memenuhi kewajibannya. Rasio solvabilitas berisikan langkah - langkah yang dimulai dengan menghitung rasio hutang terhadap ekuitas (Debt To Equity Ratio), total hutang dengan total aktiva (Debt To Total Asset Ratio), jumlah kali perolehan bunga (Time Intrest Earned), dan hutang jangka panjang terhadap ekuitas (Long Term Debt To Equity Ratio).

Saat ini Bank Indonesia mendorong penguatan daya saing dan kelembagaan bank pembangunan daerah (BPD). Bank pembangunan daerah diharapkan mampu memperkuat perekonomian daerah dan berfungsi sebagai agen pembangunan daerah setempat. PT BPD Sumatera Barat yang dikenal dengan Bank Nagari merupakan bank pembangunan daerah yang beroperasi di Sumatera Barat. Sebagai perusahaan perbankan PT BPD Sumatera Barat harus memperhatikan masalah kemampuan membayar kewajiban jangka pendek dan jangka panjangnya. Pengelolaan permodalan, keadaan keuangan dan juga manajemen yang harus dilakukan dengan sebaik - baiknya agar tingkat kemempuan bank untuk membayar kewajiban jangka pendek dan jangka panjang dapat dipelihara dengan baik serta peningkatan dan perkembangan PT BPD Sumatera Barat untuk masa yang akan datang. Berikut tabel hasil perkembangan rasio solvabilitas PT BPD Sumatera Barat tahun 2013 - 2015:

\section{Tabel 1}

Perkembangan Rasio Solvabilitas

Tahun 2013 - 2015

\begin{tabular}{|l|c|c|c|}
\hline \multicolumn{1}{|c|}{ Indikator } & $\mathbf{2 0 1 3}$ & $\mathbf{2 0 1 4}$ & $\mathbf{2 0 1 5}$ \\
\hline Debt to Total Assets Ratio & $90,59 \%$ & $90,01 \%$ & $89,00 \%$ \\
\hline Debt to Equity Ratio & $962,96 \%$ & $901,28 \%$ & $808,97 \%$ \\
\hline Long Term Debt to Equity Ratio & $65,08 \%$ & $54,19 \%$ & $46,54 \%$ \\
\hline Time Interest Earned & $0,53 \mathrm{kali}$ & $0,32 \mathrm{kali}$ & $0,41 \mathrm{kali}$ \\
\hline
\end{tabular}

Sumber : Data diolah, 2017 
Berdasarkan tabel diatas terlihat bahwa laporan keuangan PT BPD Sumatera Barat dalam rasio solvabilitas masih berfluktuasi dan cendrung menurun setiap tahun. Hal ini dapat dilihat pada tahun 2013 Debt to Total Assets Ratio diperoleh sebesar 90,59\% sedangkan pada tahun 2014 sebesar 90,01\% mengalami penurunan sebesar 0,58\% dan tahun 2015 sebesar 89,00\% mengalami penurunan sebesar $1.01 \%$ dari tahun 2014. Rasio Debt to Equity Ratio pada tahun 2013 diperoleh sebesar 962,96\% sedangkan pada tahun 2014 diperoleh sebesar 901,28\% mengalami penurunan sekitar $61.68 \%$ dan pada tahun 2015 diperoleh sebesar 808,97 yang mengalami penurunan sebesar $92,31 \%$ dari tahun sebelumnya. Rasio Long Term Debt to Equity Ratio pada tahun 2013 diperoleh sebesar 65,08\%, tahun 2014 sebesar 54,19\% dan tahun 2015 diperoleh sebesar $46,54 \%$ yang mengalami penurunan sebesar $7,65 \%$ dari tahun sebelumnya. Sedangkan rasio Time Interest Earned pada tahun 2013 diperoleh sebesar 0,53 kali tahun 2014 sebesar 0,32 kali dan pada tahun 2015 diperoleh sebesar 0,41 kali. Perumusan Masalah

Adapun perumusan masalah dalam penelitian ini yaitu bagaimana tingkat solvabilitas PT. BPD Sumatera Barat pada tahun 2013 - 2015.

\section{TINJAUAN PUSTAKA}

\section{Pengertian Bank}

Istilah bank diperkirakan berasal dari bahasa Italia yaitu Banco yang kemudian dirubah ke dalam bahasa Inggris yaitu Bank. Bank adalah satu lembaga keuangan sebagai tempat bagi perusahaan, badan - badan pemerintah, swasta maupun perorangan untuk menyimpan dana.

Menurut UU RI Pasal 1 ayat 2 No. 10 Tahun 1998 tentang perbankan mendefinisikan bank adalah sebuah badan usaha yang menghimpun dana dari masyarakat dalam bentuk simpanan dan menyalurkannya kepada masyarakat dalam bentuk kredit dan atau bentuk lainnya dalam meningkatkan taraf hidup rakyat banyak. Bank memiliki fungsi yaitu :

a. Penghimpun dana maka bank memiliki beberapa sumber yang secara garis besar ada tiga sumber yaitu:

1. Dana yang bersumber dari bank sendiri yang berupa setoran modal dari pemilik pada saat pendiriaan perusahaan

2. Dana yang berasal dari masyarakat luas yang dikumpulkan melalui usaha perbankan seperti simpanan giro, tabungan dan deposito.

3. Dana yang bersumber dari lembaga keuangan yang diperoleh dari pinjaman dana yang berupa kredit likuiditas dan call money (dana yang sewaktu waktu dapat ditarik oleh bank yang meminjam).

b. Penyalur dana yang terkumpul oleh bank disalurkan kepada masyarakat dalam bentuk pemberian kredit, pembelian surat berharga, penyertaan saham, dan pemilikan harta tetap.

c. Pelayanan jasa bank dalam mengembangkan tugas sebagai pelayanan lalulintas pembayaran uang melalui berbagai aktivitas kegiatan antara lain pengiriman uang, inkaso, kartu kredit, dan pelayanan lainnya. 


\section{Pengertian Laporan Keuangan}

Laporan keuangan merupakan hasil akhir dari suatu proses pencatatan, yang merupakan suatu ringkasan dari transaksi - transaksi keuangan yang terjadi selama tahun buku bersangkutan. Pengertian laporan keuangan menurut pernyataan standar akuntansi keuangan (PSAK) yaitu, laporan keuangan merupakan bagian dari proses pelaporan keuangan. Laporan keuangan yang lengkap biasanya meliputi laporan posisi keuangan (neraca), laporan laba - rugi komprehensif, laporan perubahan laba ditahan, laporan arus kas dan catatan atas laporan keuangan. Sedangkan menurut Munawir (2010:5) laporan keuangan terdiri atas:

a. Neraca, menginformasikan posisi keuangan pada saat tertentu, yang mencerminkan pada jumlah harta yang dimiliki, dan modal perusahaan.

b. Laporan laba rugi, menginformasikan hasil usaha suatu perusahaan selama satu periode dari berbagai aktifitas .

c. Laporan arus kas, menginformasikan perubahan dalam posisi keuangan sebagai akibat dari kegiatan usaha, pembelanjaan, dan investasi selama periode yang akan datang.

d. Catatan atas laporan keuangan, menginformasikan kebijaksanaan akuntansi yang mempengaruhi posisi keuangan dari hasil keuangan perusahaan.

Laporan keuangan diharapkan disajikan secara layak, jelas lengkap dan relevan yang mengungkapkan kenyataan - kenyataan ekonomi mengenai eksistensi dan operasi perusahaan tersebut dalam penyusunan laporan keuangan.

\section{Pengertian Analisa Laporan Keuangan}

Menurut Munawir (2012:35), analisa laporan keuangan adalah analisis laporan keuangan yang terdiri dari penelaahan atau mempelajari hubungan dan tendensi atau kecendrungan (trend) untuk menentukan posisi keuangan dan hasil operasi serta perkembangan perusahaan yang bersangkutan.

Sedangkan menurut Harahap (2009:190) analisis laporan keuangan adalah menguraikan akun - akun laporan keuangan menjadi unit informasi yang lebih kecil dan melihat hubungan yang bersifat signifikan atau yang mempunyai makna antara data kuantitatif dengan tujuan untuk mengetahui kondisi keuangan lebih dalam yang sangat menting dalam proses menghasilkan suatu keputusan yang tepat bagi perusahaan.

Berdasarkan penjelasan di atas dapat disimpulkan bahwa analisis laporan keuangan merupakan proses untuk mempelajari data - data keuangan agar dapat dipahami dengan mudah untuk mengetahui posisi keuangan, hasil operasi dan perkembangan suatu perusahaan dengan cara mempelajari hubungan data keuangan serta kecendrungan terdapat dalam suatu laporan keuangan, sehingga analisis laporan keuangan dapat dijadikan sebagai dasar dalam pengambilan keputusan bagi pihak - pihak yang berkepentingan dan juga dalam melakukan analisis tidak akan lepas dari peranan rasio - rasio keuangan yang terdapat dalam laporan keuangan sehingga dapat memutuskan suatu keputusan yang dapat diambil oleh perusahaan. Adapun tujuan atas analisis laporan keuangan yaitu:

1) Memberikan informasi yang penting mengenai posisi keuangan suatu perusahaan dan mengenai hasil operasi - operasinya. 
2) Pada umumnya analisa - analisa daiarahkan kepada pencapaian jawaban mengenai tiga pertanyaan yang ada kaitannya dengan perusahaan, yaitu mengenai likuiditas, solvabilitas dan rentabilitas perusahaan.

3) Salah satu alat pengambilan keputusan bagi manajemen, kreditur, investor atau pihak - pihak yang berkepentingan.

Menurut Harahap (2009:195) manfaat laporan keuangan yaitu:

1) Dapat memberikan informasi yang lebih luas, lebih dalam dari pada yang terdapat dalam laporan keuangan biasa.

2) Dapat menggali informasi yang tidak nampak secara kasat mata dari suatu laporan keuangan atau yang berada dibalik laporan keuangan.

3) Dapat mengetahui kesalahan yang terkandung dalam laporan keuangan.

4) Dapat memberikan informasi yang diinginkan oleh para pengambil keputusan.

5) Dapat membongkar hal - hal yang bersifat tidak konsisten dalam hubungannya dengan suatu laporan keuangan baik berkaitan dengan kompenen intern maupun kaitannya dengan informasi yang diperoleh dari luar perusahaan

Menurut Munawir (2012:36) ada dua metode analisis yang digunakan oleh setiap penganalisis laporan keuangan, yaitu analisis horizontal dan analisis vertikal. Analisis horizontal yaitu dengan mengadakan perbandingan laporan keuangan untuk beberapa periode sehingga akan diketahui perkembangannya. Sedangkan analisis vertikal yaitu apabila laporan keuangan yang dianalisis hanya meliputi suatu periode pelaporan keuangan. Menurut Munawir (2010:36) teknik analisis laporan keuangan terdiri dari:

a. Analisis perbandingan laporan keuangan, adalah metode dan teknik analisis dengan cara memperbandingkan laporan keuangan untuk dua atau lebih dengan menunjukkan:

1) Data absolut atau jumlah - jumlah dalam satuan keuangan

2) Kenaikan atau penurunan dalam jumlah rupiah

3) Kenaikan atau penurunan dalam rupiah

4) Perbandingan yang dinyatakan dalam rasio

5) Persentase dalam total

b. Posisi dan kemajuan keuangan perusahaan dinyatakan dalam persentase adalah suatu periode atau teknik analisis untuk mengetahui tandensi dari pada keadaan keuangannya, apakah menunjukkan tandensi tetap, naik atau bahkan turun.

c. Laporan keuangan persentase per komponen (common size statement), adalah suatu metode analisis untuk mengetahui persentase investasi pada masing masing aset terhadap total asetnya.

d. Analisis sumber dan penggunaan modal kerja, adalah suatu analisis untuk mengetahui sumber - sumber serta penggunaan modal kerja atau untuk mengetahui sebab - sebab berubahnya modal kerja dalam periode tertentu.

e. Analisis sumber dan penggunaan kas (Cash Flow Statement Analysis), merupakan suatu analisis untuk mengetahui sebab - sebab berubahnya jumlah uang kas atau untuk mengetahui sumber - sumber serta penggunaan uang kas selama periode tertentu. 
f. Analisis rasio adalah suatu metode analisis untuk mengetahui hubungan dari akun - akun tertentu dalam neraca atau laporan laba rugi secara individu atau kombinasi dari kedua laporan tersebut.

g. Analisis perubahan laba kotor (Gross Profit Analiysis) merupakan suatu analisis untuk mengetahui - sebab perubahan laba kotor suatu perusahaan dari satu periode ke periode lainnya.

h. Analisis Break Event, merupakan suatu analisis untuk menentukan tingkat penjualan yang harus dicapai oleh perusahaan agar perusahaan tersebut tidak mengalami kerugian, tetapi juga belum memperoleh keuntungan.

\section{Jenis - jenis Rasio Keuangan di Bank}

Rasio keuangan adalah angka yang diperoleh dari hasil perbandingan dari suatu pos laporan keuangan dengan pos lainnya yang mempunyai hubungan yang relevan dan signifikan (Syafri, 2008:297). Rasio keuangan merupakan salah satu alat untuk menilai kinerja dan kondisi keuangan perusahaan (Sawir, 2009:6). Jadi rasio keuangan merupakan salah satu jenis alat ukur yang digunakan perusahaan untuk menganalisis laporan keuangan. Jenis - jenis rasio laporan keuangan yaitu antara lain:

\section{a. Rasio Profitabilitas}

Rasio profitabilitas merupakan rasio yang digunakan untuk mengukur kemampuan perusahaan dalam menghasilkan keuntungan bagi perusahaan. Rasio ini antara lain yaitu Gross Profit Margin (GPM), Operating Profit Margin (OPM), Retur On Asset (ROA), dan Return On Equity (ROE).

Jadi melalui rasio ini, bank dapat mengetahui apakah kebijakan atau strategi yang sudah dijalankan perusahaan saat ini sudah cukup maksimal atau belum serta menentukan apakah profit yang diperoleh perusahaan sudah cukup optimal atau belum. Hal ini kemudian digunakan oleh manajemen perusahaan untuk menetapkan kebijakan untuk masa yang akan datang.

b. Rasio Likuiditas

Rasio ini digunakan untuk mengukur kemampuan perushaan dalam melunasi kewajiban - kewajiaban lancarnya. Rasio ini antara lain yaitu rasio kas (Cash Ratio), Rasio cepat (Quick Ratio), dan Rasio lancar (Current Ratio).

Jadi melalui rasio ini, bank dapat membuat keputusan segala sesuatu yang berhubungan dengan dana yang ada saat ini sudah cukup liquid atau cukup lancar atau memerlukan kebijakan lain guna meningkatkan likuiditas perusahaan dalam melunasi segala kewajiban jangka pendek perusahaan.

c. Rasio Solvabilitas

Rasio ini digunakan untuk mengukur tingkat pengelolaan sumber dana perusahaan. Rasio ini antara lain yaitu rasio hutang terhadap ekuitas perusahaan (Debt to Equity Ratio), total hutang dengan total aktiva (Debt to Total Asset Ratio), jumlah kali perolehan bunga (Time Interest Earned), dan hutang jangka panjang terhadap ekuitas (Long Term Debt to Equity Ratio).

Jadi melalui rasio ini, bank dapat memutuskan apakah dimasa yang akan datang perusahaan perlu atau tidak mencari investor atau pemberi hutang dan apakah perusahaan masih memiliki kesanggupan untuk melunasinya.

d. Rasio Aktivitas 
Rasio ini menggambarkan aktivitas yang dilakukan perusahaan dalam menjalankan operasionalnya dalam kegiatan penjualan, pembelian, dan pemberian jasa serta kegiatan lainnya. Ada dua penilaian rasio aktivitas yaitu rasio nilai pasar dan rasio efisiensi atau perputaaran. Jadi melalui rasio ini dapat diketahui apakah aktivitas yang dilakukan oleh operasional perusahaan sudah maksimal atau belum.

e. Rasio Solvabilitas dan Jenis Rasio Solvabilitas

Untuk menutupi kekurangan dan kebutuhan dana, bank memiliki beberapa pilihan sumber dana yang digunakan. Pemilihan beberapa sumber dana yangdigunakan tergantung dari tujiuan, syarat - syarat, keuntungan dan kemampuan bank. Sumber - sumber dana secara garis besar dapat diperoleh dari modal sendiri dan pinjaman (bank atau lembaga pinjaman lainnya). Bank dapat memilih dana dari salah satu sumber tersebut atau kombinasi keduanya.

Setiap sumber dana memiliki kelebihan dan kekurangan masing - masing. Misalnya penggunaan modal sendiri memiliki kelebihan, yaitu mudah diperoleh, dan beban pengambilan relatif lama. Disamping itu dengan menggunakan modal sendiri tidak ada beban untuk membayar angsuran termasuk bunga dan biaya lainnya. Sebaliknya kekurangan modal sendiri sebagai sumber dana yaitu jumlahnya yang relatif terbatas, terutama saat menjatuhkan dana yang relatif besar.

Rasio solvabilitas (Laverage) merupakan rasio yang digunakan untuk mengukur sejauh mana aktiva atau aset bank dibiayai oleh hutang. Artinya berapa besar beban utang yang ditanggung bank dibandingkan dengan asetnya. Dalam arti luas dikatakan bahwa rasio ini digunakan untuk mengukur kemampuan bank untuk membayar seluruh kewajibannya, baik jangka pendek maupun jangka panjang apabila bank dibubarkan (pailit).

Semakin tinggi rasio solvabilitas maka semakin tinggi pula resiko kerugian yang dihadapi, tetapi juga ada kesempatan memperoleh keuntungan yang besar. Sebaliknya jika bank memiliki solvabilitas yang rendah tentu mempunyai resiko kerugian yang lebih kecil. Dampak ini juga mengakibatkan rendahnya tingkat hasil pengembalian (return) pada aset perekonomian tinggi. Pengukuran rasio solvabilitas dilakukan melalui dua pendekatan yaitu:

1) Mengukur rasio - rasio dan sejauh mana pinjaman digunakan untuk permodalan.

2) Malalui pendekatan rasio - rasio laba rugi.

Manfaat rasiosolvabilitas:

1) Untuk menganalisa posisi bank terhadap kewajiban kepada pihak lainnya

2) Untuk menganalisa kemampuan bank memenuhi kewajiban yang bersifat tetap

3) Untuk menganalisa keseimbangan antara lain aktiva khususnya aktiva tetap dengan modal

4) Untuk menganalisa seberapa besar aktiva bank dibiayai oleh hutang

5) Untuk menganalisa seberapa besar hutang bank berpengaruh terhadap pengelolaan aktiva

6) Untuk menganalisa atau mengukur berapa bagian dari setiap rupiah modal sendiri yang dijadikan jaminan utang jangka panjang 
7) Untuk menganalisa berapa dana pinjaman yang segera akan ditagih ada terdapat sekian kalinya modal sendiri

Kesimpulannya dengan rasio solvabilitas, bank akan mengetahui beberapa hal yang berkaitan dengan penggunaan modal sendiri dan modal pinjaman serta mengetahui rasio kemampuan bank untuk memenuhi kewajibannya. Ada empat jenis rasio solvabilitas antara lain yaitu:

\section{1) Debt to Total Asset Ratio}

Rasio ini merupakan rasio utang yang digunakan untuk mengukur perbandingan antara total utang dengan total aktiva. Dengan kata lain seberapa besar aktiva bank dibiayai oleh utang atau seberapa besar utang bank berpengaruh terhadap pengelolaan aktiva.

Semakin tinggi rasio ini maka pendanaan dengan utang semakin banyak, maka semakin sulit bagi bank untuk memperoleh tambahan pinjaman karena dikhawatirkan perusahaan tidak mampu menutupi utang - utangnya dengan aktiva yang dimiliki. Sebaliknya rendahnya rasio ini maka semakin kecil bank yang dibiayai oleh utang.

2) Debt to Equity Ratio

Rasio ini merupakan rasio yang digunakan untuk menilai utang dengan ekuitas pemilik. Rasio ini dicari dengan cara membandingkan antara seluru hutang termasuk utang lancar dengan seluruh ekuitas. Dengan kata lain rasio ini berfungsi untuk mengetahui setiap rupiah modal sendiri yang dijadikan untuk jaminan utang.

Bagi bank semakin rendahnya rasio ini maka semakin tinggi tingkat pendanaan yang disediakan pemilik dan semakin besar batas pengamanan bagi peminjam jika terjadi kerugian atau penyusutan terhadap nilai aktiva. Rasio ini juga menunjukkan kelayakan dan resiko keuangan bank.

3) Long Term Debt to Equity Ratio

Rasio ini merupakan rasio yang digunakan untuk menilai utang jangka panjang yang dimiliki bank terhadap ekuitas pemilik. Rasio ini dengan membandingkan antara jumlah seluru hutang jangka panjang yang dimiliki bank dengan ekuitas pemilik. Dengan kata lain rasio ini berfungsi untuk melihat jaminan modal sendiri terhadap utang jangka panjang yang dimiliki oleh bank.

4) Time Interest Earned

Rasio ini juga diartikan sebagai alat ukur untuk mengukur kemampuan perusahaan untuk membayar biaya bunga, sama seperti coverage ratio. Semakin tinggi rasio ini maka semakin besar kemungkinan perusahaan memperoleh bunga pinjaman dan dapat menjadi ukuran untuk memperoleh tambahan pinjaman baru dari kreditor. Demikian pula sebaiknya apabila rasionya rendah semakin rendah pula kemampuan perusahaan untuk membayar bunga dan biaya lainnya.

\section{Analisa Rasio Solvabilitas PT BPD Sumatera Barat}

\section{Debt to Total Assets Ratio}

Debt to Total Assets Ratio menunjukkan seberapa besar aktiva bank dibiayai oleh utang atau seberapa besar utang bank berpengaruh terhadap pengelolaan aktiva. Semakin tinggi rasio ini maka pendanaan dengan utang semakin banyak. Berdasarkan data yang diperoleh debt to total assets ratio 
PT.BPD Sumatera Barat selama tahun 2013 - 2015 ditunjukkan pada table dibawah ini:

Tabel 2

Perkembangan Debt to Total Assets Ratio

Tahun 2013 - 2015

(Dalam Jutaan Rupiah)

\begin{tabular}{|l|l|l|l|}
\hline Uraian & $\mathbf{2 0 1 3}$ & $\mathbf{2 0 1 4}$ & $\mathbf{2 0 1 5}$ \\
\hline Total Assets & 16.244 .113 & 18.014 .579 & 19.448 .300 \\
\hline Liabilitas & \multicolumn{3}{|l|}{} \\
\hline Giro & 2.027 .617 & 2.362 .906 & 2.567 .309 \\
\hline Tabungan & 3.446 .067 & 3.618 .037 & 4.126 .473 \\
\hline SimpananBerjangka & 6.412 .070 & 7.251 .029 & 7.324 .144 \\
\hline Dana Investasi $(R S)$ & 401.269 & 487.387 & 596.014 \\
\hline Pinjamandari Bank Indonesia & 118 & - & - \\
\hline Pinjamandari Bank lain & 395.695 & 375.398 & 395.729 \\
\hline SuratBerharga yang diterbitkan & 598.808 & 599.531 & 600.000 \\
\hline Pinjaman yang diterima & 923.779 & 934.792 & 1.001 .947 \\
\hline Setoran Jaminan & 11.182 & 4.929 & 5.312 \\
\hline Liabilitas Pajak Tangguhan & 2.819 & - & - \\
\hline Liabilitas Lainnya & 496.490 & 581.416 & 691.771 \\
\hline Total Liabilitas & 14.715 .914 & 16.215 .425 & 17.308 .699 \\
\hline
\end{tabular}

Sumber: Data PT BPD Sumatera Barat

Formula yang digunakan untuk menentukan debt to total assets ratio yaitu sebagai berikut:

a. Untuk tahun 2013

$$
\text { Debt to Total Assets Ratio }=\frac{\text { Total Liabilitas }}{\text { Total Asset }} \times 100 \%
$$

$$
\begin{aligned}
& \text { Debt to Total Assets Ratio }= \frac{14.715 .914}{16.244 .113} \times 100 \% \\
&=90,59 \%
\end{aligned}
$$

Artinya, sebesar $90,59 \%$ pendanaan bank dibiayai dari utang atau setiap Rp 1 dana bank, Rp 0,90 dibiayai oleh utang perusahaan dan Rp 0,10 dibiayai oleh pemegang saham.

b. Untuk tahun 2014

$$
\begin{aligned}
\text { Debt to Total Assets Ratio }=\frac{16.228 .698}{18.017 .897} \times 100 \% \\
=90,01 \%
\end{aligned}
$$

Artinya, sebesar $90,01 \%$ pendanaan bank dibiayai dari utang atau setiap Rp 1 dana bank, Rp 0,90 dibiayai oleh utang perusahaan dan $\operatorname{Rp~0,10~}$ dibiayai oleh pemegang saham.

c. Untuk tahun 2015

$$
\begin{aligned}
& \text { Debt to Total Assets Ratio }=\frac{17.308 .699}{19.448 .300} \times 100 \% \\
& =89,00 \%
\end{aligned}
$$

Artinya, sebesar $89,00 \%$ pendanaan bank dibiayai dari utang atau setiap Rp 1 dana bank, Rp 0,89 dibiayai oleh utang perusahaan dan Rp 0,11 dibiayai oleh pemegang saham.

Dari analisa debt to total asset ratio dapat disimpulkan bahwa secara keseluruhan PT. BPD Sumatera Barat dilihat dari tahun 2013 - 2015, bahwa keseluruhan aset perusahaan mampu menutupi seluruh utang perusahaan. 


\section{Debt to Equity Ratio}

Rasio ini digunakan untuk mengetahui setiap rupiah modal sendiri yang dijadikan untuk jaminan utang. Semakin rendah rasio ini maka semakin tinggi tingkat pendanaan yang disediakan pemilik dan semakin besar batas pengamanan bagi peminjam jika terjadi kerugian terhadap nilai aktiva. Berdasarkan data yang diperoleh debt to equity ratio PT. BPD Sumatera Barat selama tahun 2013 -2015 terlihat pada tabel di bawahini:

\section{Tabel 3}

Perkembangan Debt to Equity Ratio

Tahun 2013 - 2015

(Dalam Jutaan Rupiah)

\begin{tabular}{|c|c|c|c|}
\hline Uraian & 2013 & 2014 & 2015 \\
\hline Total Ekuitas & 1.528 .199 & 1.789 .199 & 2.139 .601 \\
\hline \multicolumn{4}{|l|}{ Liabilitas } \\
\hline Giro & 2.027 .617 & 2.362 .906 & 2.567 .309 \\
\hline Tabungan & 3.446 .067 & 3.618 .037 & 4.126 .473 \\
\hline Simpanan Berjangka & 6.412 .070 & 7.251 .029 & 7.324 .144 \\
\hline Dana Investasi $(R S)$ & 401.269 & 487.387 & 596.014 \\
\hline Pinjaman dari Bank Indonesia & 118 & - & - \\
\hline Pinjaman dari Bank lain & 395.695 & 375.398 & 395.729 \\
\hline Surat Berharga yang diterbitkan & 598.808 & 599.531 & 600.000 \\
\hline Pinjaman yang diterima & 923.779 & 934.792 & 1.001 .947 \\
\hline Setoran Jaminan & 11.182 & 4.929 & 5.312 \\
\hline Liabilitas Pajak Tangguhan & 2.819 & - & - \\
\hline Liabilitas Lainnya & 496.490 & 581.416 & 691.771 \\
\hline Total Liabilitas & 14.715 .914 & 16.215 .425 & 17.308 .699 \\
\hline
\end{tabular}

Sumber: Data PT BPD Sumatera Barat

Formula yang digunakan untuk menentukan debt to equity ratio yaitu sebagai berikut:

$$
\text { Debt to Equity Ratio }=\frac{\text { Total Liabilitas }}{\text { Total Equity }} \times 100 \%
$$

a. Untuk tahun 2013

$$
\begin{aligned}
& \text { Debt to Equity Ratio }=\frac{14.715 .914}{1.528 .199} \times 100 \% \\
& =962,96 \%
\end{aligned}
$$

Artinya, sebesar Rp 9,63 dari setiap rupiah modal sendiri menjadi jaminan utang atau bank dibiayai oleh utang sebesar $962,96 \%$. Sebagian besar modal bank berasal dari pihak ke tiga, maka total hutang bank sangat besar, karena hutang ini memperoleh sumber dana yang akan di salurkan dalam bentuk kredit.

b. Untuk tahun 2014

$$
\begin{aligned}
& \text { Debt to Equity Ratio }=\frac{16.215 .425}{1.799 .154} \times 100 \% \\
& =901,28 \%
\end{aligned}
$$

Artinya, sebesar Rp 9 dari setiap rupiah modal sendiri menjadi jaminan utang atau bank dibiayai oleh utang sebesar 901,28\%. Sebagian besar modal bank berasal dari pihak ke tiga, maka total hutang bank sangat besar, karena 
hutang ini memperoleh sumber dana yang akan di salurkan dalam bentuk kredit.

c. Untuk tahun 2015

$$
\begin{aligned}
& \text { Debt to Equity Ratio }=\frac{17.308 .699}{2.139 .601} \times 100 \% \\
& =808,97 \%
\end{aligned}
$$

Artinya, sebesar Rp 8 dari setiap rupiah modal sendiri menjadi jaminan utang atau bank dibiayai oleh utang sebesar $808,97 \%$. Sebagian besar modal bank berasal dari pihak ke tiga, maka total hutang bank sangat besar, karena hutang ini memperoleh sumber dana yang akan di salurkan dalam bentuk kredit.

Dari hasil analisis yang dilakukan dapat ditarik kesimpulan jika dilihat dari debt to equity ratio PT. BPD Sumatera Barat tahun 2013 - 2015, bahwa modal sendiri belum mampu menutupi keseluruhan utang bank.

\section{Long Term Debt to Equity Ratio}

Rasio ini merupakan rasio yang digunakan untuk menilai utang jangka panjang yang dimiliki bank terhadap ekuitas pemilik. Rasio ini dengan membandingk anantara jumlah seluru hutang jangka panjang yang dimiliki bank dengan ekuitas pemilik. Berdasarkan data yang diperoleh long term debt to equity ratio PT. BPD Sumatera Barat Tahun 2013 - 2015 ditujukan pada table dibawah ini:

\section{Tabel 4}

\section{PerkembanganLong Term Debt to Equity Ratio}

Tahun 2013 - 2015

(Dalam Jutaan Rupiah)

\begin{tabular}{|l|l|l|l|}
\hline Uraian & $\mathbf{2 0 1 3}$ & $\mathbf{2 0 1 4}$ & $\mathbf{2 0 1 5}$ \\
\hline Total Ekuitas & 1.528 .199 & 1.789 .199 & 2.139 .601 \\
\hline Long Term Liabilities & 118 & - & - \\
\hline Pinjamandari Bank Indonesia & 395.695 & 375.398 & 395.729 \\
\hline Pinjamandari Bank lain & 598.808 & 599.531 & 600.000 \\
\hline SuratBerharga yang diterbitkan & 994.621 & 974.929 & 995.729 \\
\hline Total Long Term Liabilities &
\end{tabular}

Sumber: Data PT BPD Sumatera Barat

Formula yang digunakan untuk menentukan long term debt to equity ratio yaitu sebagai berikut:

$$
\text { Long Term Debt to Equity Ratio }=\frac{\text { Total Long Term Liabilities }}{\text { Total Equity }} \times 100 \%
$$

a. Untuk tahun 2013

$$
\begin{array}{r}
\text { Long Term Debt to Equity Ratio }=\frac{994.621}{1.528 .199} \times 100 \% \\
=65,08 \%
\end{array}
$$

Artinya, sebesar Rp 0,65 dari setiap rupiah modal sendiri menjadi jaminan utang jangka panjang atau operasional bank dibiayai $65 \%$ dari utang jangka panjang.

b. Untuk tahun 2014

$$
\text { Long Term Debt to Equity Ratio }=\frac{974.929}{1.789 .199} \times 100 \%
$$




$$
=54,19 \%
$$

Artinya, sebesar Rp 0,54 dari setiap rupiah modal sendiri menjadi jaminan utang jangka panjang atau operasional bank dibiayai 54\% dari utang jangka panjang

c. Untuk tahun 2015

$$
\begin{gathered}
\text { Long Term Debt to Equity Ratio }=\frac{995.729}{2.139 .601} \times 100 \% \\
=46,54 \%
\end{gathered}
$$

Artinya, sebesar Rp 0,46 dari setiap rupiah modal sendiri menjadi jaminan utang jangka panjang atau operasional bank dibiayai $46,54 \%$ dari utang jangka panjang.

Dari data diatas dapat ditarik kesimpulan bahwa dilihat dari tahun 2013 - 2015 untuk long term debt to equity ratio PT. BPD Sumatera Barat padatahun 2013 long term debt to equity ratiosebanyak 0,65. Tahun 2014 long term debt to equity ratio menurun menjadi 0,54. Pada tahun 2015 menurun lagi menjadi 0,46 ini berarti semakin kecil rasio semakin buruk. Artinya perusahaan lebih kecil menggunakan modal sendiri dibandingkan menggunakan hutang jangka panjang.

4. Time Interest Earned

Rasio ini menggambarkan kemampuan bank untuk memenuhi kewajiban tetapnya, dalam membayar Bunga dari sejumlah laba sebelum bunga dan pajak (EBIT). Berdasarkan data yang diperoleh time interest earned PT. BPD Sumatera Barat selama periode tahun 2013 - 2015 ditujukan pada table dibawah ini:

\section{Tabel 5}

Perkembangan Time Interest Earned

Tahun 2013 - 2015

(Dalam Jutaan Rupiah)

\begin{tabular}{|l|l|l|l|}
\hline Uraian & $\mathbf{2 0 1 3}$ & $\mathbf{2 0 1 4}$ & $\mathbf{2 0 1 5}$ \\
\hline Laba Rugi Tahun Berjalan & 421.819 & 335.000 & 430.272 \\
\hline Beban Bunga & 802.160 & 1.037 .720 & 1.049 .255 \\
\hline
\end{tabular}

Sumber: Data PT BPD Sumatera Barat

Formula yang digunakan untuk menentukan time interest earned yaitu sebagai berikut:

a. Untuk tahun 2013

$$
\text { Time Interest Earned }=\frac{\text { Laba Rugi Tahun Berjalan }}{\text { Beban bunga }} \times 100 \%
$$

$$
\begin{aligned}
\text { Time Interest Earned }= & \frac{421.819}{802.160} \times 100 \% \\
& =0,53 \mathrm{kali}
\end{aligned}
$$

Artinya, dapat digunakan untuk melihat kemampuan perusahaan membayar bunga dan hutang. Jika menggunakan perbandingan lebih dari satu periode maka nilai time interest earned semakin besar akan semakin bagus, dalam artian EBIT (laba sebelum bunga dan pajak) yang dimiliki perusahaan lebih besar nilainya dari pada beban bunga yang harus di bayar. Jika nilai Time 
Interest Earned 0,53 maka biaya bunga belum dapat di tutup sebesar 0,53 kali dari laba sebelum bunga dan pajak.

b. Untuk tahun 2014

$$
\begin{aligned}
& \text { Time Interest Earned }=\frac{335.000}{1.037 .720} \times 100 \% \\
& =0,32 \mathrm{kali}
\end{aligned}
$$

Artinya, dapat digunakan untuk melihat kemampuan perusahaan membayar bunga dan hutang. Jika menggunakan perbandingan lebih dari satu periode maka nilai time interest earned semakin besar akan semakin bagus, dalam artian EBIT (laba sebelum bunga dan pajak) yang dimiliki perusahaan lebih besar nilainya dari pada beban bunga yang harus di bayar. Jika nilai Time Interest Earned 0,32 maka biaya bunga belum dapat di tutup sebesar 0,32 kali dari laba sebelum bunga dan pajak.

c. Untuk tahun 2015

$$
\begin{aligned}
& \text { Time Interest Earned }=\frac{430.272}{1.049 .255} \times 100 \% \\
& =0,41 \mathrm{kali}
\end{aligned}
$$

Artinya, biaya bunga belum dapat ditutup sebesar 0,41 kali dari laba sebelum bunga dan pajak yang diperoleh perusahaan.

Sehingga dapat ditarik kesimpulan untuk time interest earned PT. BPD Sumatera Barat bahwa laba sebelum bunga dan pajak sangat kecil ini dapat di lihat dari tahun 2013 dengan nilai time interest earnedsebesar 0,53 kali. Pada tahun 2014 time interest earned PT. BPD Sumatera Barat menurun menjadi 0,32 kali dan pada tahun 2015 meningkat menjadi 0,4 kali. Ini dapat di simpulkan PT. BPD Sumatera Barat belum mampu untuk menutupi atau membayar beban bunga bank. Secara umum jika nilai time interest earned kecil dari 1,5 kali termasuk tidak aman karena bank hanya mampu untuk membayar bunga.

\section{SIMPULAN}

Berdasarkan hasil analisis pada bab sebelumnya, dapat ditarik kesimpulan sebagai berikut:

Gambaran tingkat solvabilitas PT. BPD Sumatera Barat selama periode tahun 2013 - 2015 dapat disimpulkan bahwa:

1) Debt to total asset ratio dari tahun 2013 sampai 2015 menunjukkan nilai yang baik karena assets yang dimiliki perusahaan mampu membayar utang perusahaan serta nilainya selalu berkurang setiap tahun. DTAR tahun 2013 sebesar 90,59\% sedangkan tahun 2014 mengalami penurunan sebesar 0,58\% menjadi 90,01\% dan untuk tahun 2015 diperoleh sebesar 89,00\%.

2) Dilihat dari debt to equity ratio pada PT. BPD Sumatera Barat terlalu tinggi karena tingginya nilai utang yang dimiliki perusahaan dibandingkan modal. Pada tahun 2013 DER diperoleh sebesar 962,96\% sedangkan tahun 2014 mengalami penurunan sebesar 61,68\% sehingga DER tahun 2014 diperoleh sebesar 901,28\% dan untuk tahun 2015 DER diperoleh sebesar 808,97\%. Nilai untuk debt to equity ratio semakin rendah nilainya maka akan semakin baik bagi bank karena modal akan mampu membayar utang. 
3) Dilihat dari long term debt to equity ratio dari tahun 2013 sampai 2015 menunjukkan nilai yang baik hali ini dapat dilihat dari LTDER tahun 2013 sebesar 65,08\% sedangkan tahun 2014 mengalami penurunan sebesar 10,89\% menjadi 54,19\% dan untuk tahun 2015 diperoleh sebesar 46,54\%.

4) Time interest earned tahun 2013 sampai 2015 menunjukkan nilai yang kurang baik karena rasio perputaran diperoleh terlalu kecil. Pada tahun 2013 TIE diperoleh sebesar 0,53 kali sedangkan pada tahun 2014 0,32 kali sedangkan untuk tahun 2015 diperoleh sebesar 0,41 kali. Hal ini disesabkan karena EBIT setiap tahunnya terlalu rendah dibanding beban bunga. Untuk rasio ini semakin tinggi maka akan semain baik bagi bank untuk membayar beban bunga.

\section{DAFTAR PUSTAKA}

Arifin, I. Z., \& Marlius, D. (2017). Analisis Kinerja Keuangan PT. Pegadaian Cabang Ulak Karang. https://doi.org/10.31227/osf.io/n2peu

Fahmi Irham, 2011. Analisis Kinerja Keuangan, Penerbit, CV . Alfabeta, Jakarta.

Gibson James L, 1997. Organisasi dan Struktur Organisasi, Penerbit Erlangga, (edisi ke-2)

Jumingan, 2008. Analisa Laporan Keuangan, Penerbit, PT. Bumi Aksara, Jakarta.

Mamduh M. Hanafi, Analisis Laporan Keuangan, Penerbit UPP AMP YKPN, Yogyakarta, 2001.

Munawir, Analisa Laporan Keuangan, Edisi Keempat, Penerbit Liberty, Yogyakarta, 1998.

Oktavia, L., \& Fernos, J. (2019). Analisis Laporan Keuangan Berdasarkan Tingkat Rentabilitas Bank Perkreditan Rakyat (BPR) Batang Palangki. https://doi.org/10.31227/osf.io/tbqdv

Putri, Y. A., \& Marlius, D. (2018). Analisis Tingkat Kesehatan Bank Pada PT. Bank Perkreditan Rakyat (BPR) Jorong Kampuang Tangah Pariaman Cabang Padang. https://doi.org/10.31227/osf.io/r98pv

Rahmayeli, D. S., \& Marlius, D. (2017). Analisis Kinerja Keuangan Pada PT. Bank Perkreditan Rakyat (BPR) Batang Kapas Pesisir Selatan. https://doi.org/10.31227/osf.io/sz5db

Sawir, Agnes, 2009. Analisa Kinerja Keuangan dan Perencanaan Keuangan Perusahaan, PT. Gramedia Pustaka Utama, Jakarta. 
Suherti, E., \& Fernos, J. (2019). Analisa Rasio Terhadap Laporan Keuangan Pada PT. Bank Pembangunan Daerah Sumatera Barat. https://doi.org/10.31227/osf.io/9zte8

Syafri Harahap, Sofyan, 2008. Analisa Kritis atas Laporan Keuangan, PT. Raja Grafindo Persada, Jakarta.

Tim IkatanAkuntan Indonesia.(2007). StandarAkuntansiKeuangan. Jakarta: SalembaEmpat.

Tunggal, Amin Widjaja. (1994). Dasar-dasarAnalisisLaporanKeuangan. Jakarta: PT. RinekaCipta

http://nasional.sindonews.com/read/719656/18/menggagas-indikator-efisiensi$\underline{1361338674 w w w . b a n k n a g a r i . c o . i d}$ 